\title{
The Development of Competency-Based Training Model for Studio Operational Techniques About Problem Based Learning for Camera Operator Instructors

\author{
Ezriani, Nizwardi Jalinus, Jamaris Jamna.
}

\begin{abstract}
This development research is aimed to develop training procedures that can help participants implement the results of the training in their respective assignments. Validation is carried out by experts in education by providing a questionnaire to fill out. This method was chosen so that the validator can provide conclusions (invalid, less valid, quite valid, valid, and very valid) directly on each part of the research product which includes competency-based training guides, training programs, lesson plans, and problem-based learning design modules for studio operational instructor, camera operator subject.
\end{abstract}

Keywords: training, problem-based learning, camera operator

\section{INTRODUCTION}

The government always strives to improve the quality of education through the Ministry of Human Resources of the Republic of Indonesia (Kemnaker). Improving the quality of education and instructor knowledge strengthens and access to job training to improve the competence of Indonesian human resources (HR). In addition, the Ministry of Human Resources also continues to promote training programs to support the acceleration of competency improvement, it is hoped that the training and learning carried out will be of good quality. The end result is expected to improve the quality of instructors. This is in line with the vision of national education, namely:

"The realization of the education system as a strong and authoritative social institution to empower all Indonesian citizens to develop into qualified human beings so that they are able and proactive in responding to the challenges of the ever-changing times" [2].

This can be done if the instructor's paradigm is changed from teaching to learning. Teaching is a process that activates the instructor to help participants understand a concept. between the instructor and the participants, learning resources, and friends.

Manuscript received on March 11, 2021

Revised Manuscript received on March 25, 2021

Manuscript published on March 30, 2021.

* Correspondence Author

Ezriani*, Universitas Negeri Padang, Indonesia.

Nizwardi Jalinus, Professor Universitas Negeri Padang, Indonesia.

Jamaris Jamna, Profesor Universitas Negeri Padang, Indonesia.

(C) The Authors. Published by Blue Eyes Intelligence Engineering and Sciences Publication (BEIESP). This is an open access article under the CC BY-NC-ND license (http://creativecommons.org/licenses/by-nc-nd/4.0/)
Participants actively learn if there is an interaction

Therefore, the instructor must be able to create learning situations so that participants can discuss with their friends and can gather information from related learning sources, diverse lessons. Hence, the learning process is more flexible, challenging, varied, fun, motivating, according to the talents, interests, and physical development, and areas of expertise of each participant. Learning that accommodates this uses a process of exploration, elaboration, and confirmation. As stated in the Ministry of National Education Regulation No. 41 of 2007 as follows.

"The exploration process involves students looking for broad and deep information about the topic/theme of the material being studied by applying the natural principle of "alam takambang jadi guru" and learning from various sources. The elaboration process by familiarizing students with various reading and writing through certain meaningful tasks. The confirmation process is that the teacher provides positive feedback and reinforcement in the form of oral, written, cues, and prizes for the success of students "[3].

The exploration process applies the natural principle of nature to become a teacher so that contextual learning strongly supports this principle. Contextual learning is directed at solving real problems carried out in group learning. This helps students play a role and be responsible as members of the family, community, students and workers.

The theory above is not in accordance with the reality in the TVRI Training Center. The training participants have started to have the ability to find relevant information from various sources about the material being studied. So that they have experience and can form schemata of the material they learn. The results of observations carried out at the TVRI Education and Training Center regarding composing the composition of camera operation, the media used in learning in the form of visuals and images that can affect the thinking power of participants through the five senses. (learning in the form of a chart) which contains six elements of competence, title, and learning objectives. Furthermore, the methods used were discussion and question and answer, the facilities used by the blackboard and evaluation were in the form of essays and practice tests that were given at the end of the lesson. The instructor emphasizes things that are core concepts and displays visual (chart) conclusions of the subject matter and asks participants to take notes. The instructor distributes quiz questions and asks the training participants to answer by closing the book. 
Tabel 1 The Result of Observation

\begin{tabular}{|c|c|c|c|}
\hline \multirow[t]{2}{*}{ No } & \multirow{2}{*}{$\begin{array}{c}\text { Object of } \\
\text { Observation }\end{array}$} & \multicolumn{2}{|c|}{ Subject of Observation } \\
\hline & & TOS Training & $\begin{array}{c}\text { Production } \\
\text { Training } \\
\end{array}$ \\
\hline 1 & Media & \begin{tabular}{l||} 
Chart / visual \\
containing visual \\
element material is \\
composed in a frame \\
\end{tabular} & $\begin{array}{l}\text { Video image media } \\
\text { via LCD. }\end{array}$ \\
\hline 2 & Method & $\begin{array}{l}\text { Discussion, questions } \\
\text { and answers, and } \\
\text { practice }\end{array}$ & $\begin{array}{l}\text { Discussion and } \\
\text { question and answer }\end{array}$ \\
\hline 3 & Evaluation & $\begin{array}{l}\begin{array}{l}\text { Essay and practice } \\
\text { tests }\end{array} \\
\end{array}$ & Multiple-choice test \\
\hline 4 & $\begin{array}{l}\text { Learning Process: } \\
\text { a. Pre-Teaching }\end{array}$ & $\begin{array}{l}\text { The instructor asks } \\
\text { about the elements of } \\
\text { the composition }\end{array}$ & \begin{tabular}{|l|} 
The instructor asks \\
questions about the \\
production process \\
\end{tabular} \\
\hline & $\begin{array}{l}\text { b. While- } \\
\text { Teaching }\end{array}$ & $\begin{array}{l}\text { - participants in } \\
\text { groups discuss to } \\
\text { answer questions. } \\
\text { - presentation of } \\
\text { discussion results }\end{array}$ & \begin{tabular}{|l|} 
- Participants \\
discuss LDP in \\
groups \\
- Instructors guide \\
participants during \\
the discussion \\
participants present \\
the results of the \\
discussion \\
\end{tabular} \\
\hline & a. $\quad$ Post-teaching & $\begin{array}{l}\text { the instructor } \\
\text { emphasizes the } \\
\text { material being } \\
\text { studied } \\
\text { - the instructor } \\
\text { distributes quiz } \\
\text { questions } \\
\text { The instructor } \\
\text { conveys the tasks } \\
\text { that the participants } \\
\text { must d } \\
\end{array}$ & \begin{tabular}{|l|} 
The instructor asks \\
participants to \\
conclude the \\
material that has \\
been discussed \\
- The instructor \\
provides an \\
evaluation in the \\
form of multiple- \\
choice questions
\end{tabular} \\
\hline
\end{tabular}

The results of the two observations in table 1 above can be concluded that the learning carried out by the instructor are not in accordance with the exploration, elaboration, and confirmation process as outlined by the government through the Minister of National Education Regulation no. 41 of 2007. In the exploration process, participants were not given the opportunity to look for materials from other learning sources, but only on one PowerPoint material and waited for information provided by the instructor. The use of less varied media and methods. Interaction occurs only among participants and the material only contains material on power points. This means that the information received by participants from one type of PowerPoint material from the instructor. This causes participants to be not active in learning, but instructors who are always active in teaching. Gijbels stated PBL is a way of learning that leads to a training process based on actual problems. The emphasis on actual problems in this learning process is the most important thing. [5]. Meanwhile, Levin stated PBL is a learning method that encourages training participants to apply critical thinking, problem-solving skills and gains knowledge about the real problems and issues it faces [7].

\section{II.METHOD}

The method in this research is the development method (R\&D) with the Dubois model [4]. The research data were collected and analyzed qualitatively and quantitatively. Qualitative analysis is used for qualitative data regarding the need for problem-based learning (this data is collected to see which parts of problem-based learning are not understood by instructors. Meanwhile, quantitative analysis is used to obtain the validity, practicality, and effectiveness of this

development research. This only examines the needs analysis of instructors and participants in competency-based training in studio operational techniques on problem-based learning.

\section{III.RESULT AND DISCUSSION}

This development process is divided into two parts, first, the development of competency-based training for camera operator instructors. Second, the validity, practicality, and effectiveness of research products.

The validity of the studio operational technique competency-based training model book on problem-based learning (PBL) camera operators is seen from the aspects of substance, presentation, and language. The validity results use the content-Aiken's V validity coefficient and Is Lawshe's VCR validity.

\section{a. Content validity coefficient-aiken's $v$ and content validity-Lawshe's VCR}

Content-Aiken's V validity is used to calculate the content-validity coefficient which is based on the results of the assessment from a panel of $n$ people on an item in terms of the extent to which the item represents the measured construct is a training model book based on competency instudio operational techniques on problem-based learning ( PBL) camera operator with Fill-Aiken's V Validity Coefficient, the display of the results can be seen in table 2 .

Table 2 Content Validation Coefficient Results - Aiken's V Book Development Technical Operations Competency-Based Training on Learning PBL's Studio Camera Operator

\begin{tabular}{|c|c|c|c|c|c|c|}
\hline \multirow[t]{2}{*}{$\begin{array}{c}\text { Assessor } \\
\text { (validator) }\end{array}$} & \multicolumn{2}{|c|}{$\begin{array}{c}\text { Item } 1 \\
\text { (substance) }\end{array}$} & \multicolumn{2}{|c|}{$\begin{array}{c}\text { Item } 2 \\
\text { (presentation } \\
\text { aspect) }\end{array}$} & \multicolumn{2}{|c|}{$\begin{array}{c}\text { Item } 3 \\
\text { (language } \\
\text { aspect) }\end{array}$} \\
\hline & Score & $\mathrm{S}$ & Score & $\mathrm{S}$ & Score & $\mathbf{S}$ \\
\hline$\overline{\mathrm{Y}}$ & 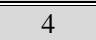 & 3 & $\overline{3}$ & 2 & 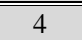 & 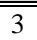 \\
\hline $\mathrm{R}$ & 4 & 3 & 4 & 3 & 4 & 3 \\
\hline B & 4 & 3 & 4 & 3 & 3 & 2 \\
\hline $\mathrm{Y}$ & 3 & 2 & 3 & 2 & 4 & 3 \\
\hline $\mathrm{R}$ & 4 & 3 & 4 & 3 & 4 & 2 \\
\hline$S$ & 4 & 3 & 4 & 3 & 2 & 1 \\
\hline$\sum \mathbf{s}$ & \multicolumn{2}{|c|}{17} & \multicolumn{2}{|c|}{16} & \multicolumn{2}{|c|}{15} \\
\hline V V & \multicolumn{2}{|c|}{0.607 (valid) } & \multicolumn{2}{|c|}{0.571 (valid) } & \multicolumn{2}{|c|}{0.536 (valid) } \\
\hline
\end{tabular}

Based on the data on the table 2 above we can draw conclusions. The value of $\mathrm{V}$ for item 1 (substance aspect) is obtained from $\mathrm{V}=17$ / $(6(5-1))=0.607$, as well as item 2 (presentation aspect), namely $\mathrm{V}=16(6(5-1))=0.571$ while for item 3 (language aspect), namely $\mathrm{V}=15$ (6 (5-1)) = 0.536 , from the three items of content validity - Aiken's V on the training model book based on competency in studio operational techniques on problem based learning (PBL) camera operators

From these three aspects, it can be concluded that the training model book based on competency in-studio operational techniques on problem-based learning (PBL) for camera operators, has valid content validity. 
b. Content validity-Lawshe's VCR

On the other hand, researchers also use Content Validity Lawshe's VCR, used to measure agreement among evaluators (validators) about the importance of certain items, in the studio operational technique competency-based training model book on problem-based learning (PBL) camera operators, the results can be seen in table 4 .

Table 4. Results of Content Validation of Lawshe's VCR Books Technical Operations Competency Based Training on Learning PBL Studio Camera Operator

\begin{tabular}{|c||c|c||}
\hline No & Assesors & Category \\
\hline \hline 1 & $\mathrm{Y}$ & Important \\
\hline \hline 2 & $\mathrm{R}$ & Important \\
\hline \hline 3 & $\mathrm{~B}$ & Important \\
\hline \hline 4 & $\mathrm{Y}$ & Important \\
\hline \hline 5 & $\mathrm{R}$ & Unimportant \\
\hline \hline 6 & $\mathrm{~S}$ & Important \\
\hline \hline \multicolumn{2}{|c||}{} & Important category \\
\hline
\end{tabular}

There are 6 expert panelists, 5 people said the item was "important", 1 person said "appropriate, not important", (See table 4). From this data, the CVR can then be calculated: CVR $=((5-(6 / 2)) /(6 / 2)$ CVR $=0.667$ shows that the items used have met good content validity and are considered "important" more than half of expert as a judge.

1) Training Program, Syllabus and Training RPP

a. Content Validity - Aiken's V

The results of the content-Aiken validity, for the training program, syllabus, and training lesson plans can be seen in Table 28 below.

Table 5 Results of Content-Aiken's Validity Training Program, Syllabus, and Lesson Plan of Training

\begin{tabular}{|c|c|c|c|c|}
\hline \multirow{2}{*}{$\begin{array}{l}\text { Assessor } \\
\text { (validator) }\end{array}$} & \multirow{2}{*}{$\begin{array}{c}\begin{array}{c}\text { Item 1 } 1 \\
\text { Training Program } \\
\text { and Syllabus }\end{array} \\
\text { Score }\end{array}$} & \multicolumn{3}{|c|}{$\begin{array}{c}\text { Item } 2 \\
\text { Lesson Plan of Trainig }\end{array}$} \\
\hline & & $\overline{S S}$ & Score & S \\
\hline$\overline{\mathrm{Y}}$ & 4 & 3 & 3 & 2 \\
\hline $\bar{R}$ & 4 & 3 & 4 & 3 \\
\hline B & 4 & 3 & 4 & 3 \\
\hline $\bar{Y}$ & 4 & 3 & 4 & 3 \\
\hline$\overline{\mathrm{R}}$ & 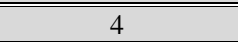 & 3 & 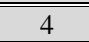 & 3 \\
\hline $\bar{S}$ & $\overline{4}$ & 3 & 4 & 3 \\
\hline$\sum \mathbf{s}$ & 18 & \multicolumn{3}{|c|}{16} \\
\hline $\mathbf{V}$ & 0.643 (valid) & \multicolumn{3}{|c|}{0.571 (valid) } \\
\hline
\end{tabular}

Based on the table 5 above we can draw conclusions. The value of $\mathrm{V}$ for item 1 (training program and syllabus) is obtained from $\mathrm{V}=18 /(6(5-1))=0.643$, while item 2 $(\mathrm{RPP})$ is $\mathrm{V}=16(6(5-1))=0.571$ of the items 1 and 2 content validity - Aiken's V above already has valid content validity.

The results of the validity of the training program, syllabus, and lesson plans in Table 5 above are categorized as valid. The results of the validity of the training program and syllabus have a validity coefficient of Aiken's V of 0.643 categorized as valid. The results of the validity for the RPP obtained the validity of Aiken's V coefficient of 0.571 categorized as valid.

\section{b. Content validity-Lawshe's VCR}

The results of the Content Validity - Lawshe's VCR, used to measure agreement among the evaluators (validators) about the importance of certain items, in the studio operational technique competency-based training model book on problem-based learning (PBL) camera operators, the results can be seen in table 6 .

Table 6 Results of Content- Lawshe's VCR Training Program, Syllabus, and Lesson Plan of Training

\begin{tabular}{|c|c|c|}
\hline No & Assesors & Category \\
\hline 1 & $\mathrm{Y}$ & Important \\
\hline 2 & $\mathrm{R}$ & Important \\
\hline 3 & $\mathrm{~B}$ & Important \\
\hline 4 & $\overline{\mathrm{Y}}$ & Important \\
\hline 5 & R & Important \\
\hline 6 & $\mathrm{~S}$ & Important \\
\hline & & Important category \\
\hline
\end{tabular}

CVR $=($ ne $-\mathrm{N} / 2) /(\mathrm{N} / 2)$, where CVR is the content validity ratio, ne is the number of panelist members who answered "important", $\mathrm{N}$ is the total number of panelists, out of 6 expert panels, 6 people stated items is "important", (See table 31). From this data, the CVR can then be calculated as follows: $\mathrm{CVR}=((6-(6 / 2)) /(6 / 2) \mathrm{CVR}=1$, then the CVR value is 1 , indicating that the item used has met good content validity and considered important by the expert used as an appraiser.

\section{b. Training Module for Camera Operators}

a. Validity of Is -Aiken's V

The results of the content validity -Aiken's, for the Training Module for Participants can be seen in Table 7 below.

Table 7 Results Content Validity - Aiken's V Module Operational Technical Competency Based Training Studio Camera Operator About to Participants

\begin{tabular}{|c|c|c|c|c|c|c|}
\hline \multirow[t]{2}{*}{$\begin{array}{c}\text { Assessor } \\
\text { (validator) }\end{array}$} & \multicolumn{2}{|c|}{$\begin{array}{c}\text { Item 1 } \\
\text { (substance) }\end{array}$} & \multicolumn{2}{|c|}{$\begin{array}{c}\text { Item } 2 \\
\text { (presentation } \\
\text { aspect) }\end{array}$} & \multicolumn{2}{|c|}{$\begin{array}{c}\text { Item } 3 \\
\text { (language } \\
\text { aspect) }\end{array}$} \\
\hline & Score & $\mathbf{S}$ & Score & $\mathbf{s}$ & Score & $\mathrm{S}$ \\
\hline $\mathrm{Y}$ & 4 & 3 & 4 & 3 & 3 & 2 \\
\hline $\mathrm{R}$ & 4 & 3 & 4 & 3 & 4 & 3 \\
\hline B & 4 & 3 & 4 & 3 & 4 & 3 \\
\hline $\mathrm{Y}$ & 4 & 3 & 4 & 3 & 4 & 3 \\
\hline $\mathrm{R}$ & 4 & 3 & 3 & 2 & 4 & 3 \\
\hline S & 4 & 3 & 4 & 3 & 4 & 3 \\
\hline$\sum \mathbf{s}$ & \multicolumn{2}{|c|}{18} & \multicolumn{2}{|c|}{18} & \multicolumn{2}{|c|}{17} \\
\hline $\mathbf{V}$ & \multicolumn{2}{|c|}{0.643 (valid) } & \multicolumn{2}{|c|}{0.643 (valid) } & \multicolumn{2}{|c|}{0.607 (valid) } \\
\hline
\end{tabular}

The data of table 7 above shows the conclusions. The value of $\mathrm{V}$ for item 1 (substance aspect) is obtained from $\mathrm{V}=18$ / $(6(5-1))=0.643$, as well as item 2 (presentation aspect), namely $\mathrm{V}=18(6(5-1))=0.643$ while for item 3 (language aspect), namely $\mathrm{V}=17(6(5-1))=0.607$, of the three content validity items - Aiken's V in table 7 above the training module based on competency in-studio operational techniques on problem-based learning (PBL) camera operators for participants in the "valid" category.

After calculating based on the validity of Aiken's V, based on the criteria for the validity value of Aiken's V, it can be seen in Table 7 that the results of the Aiken's V content validity coefficient on the training module based on competency in-studio operational techniques on problembased learning (PBL) camera operators for participants are categorized " valid". 
The final average score of the training module based on competency in-studio operational techniques on problembased learning (PBL) camera operators for participants is categorized as valid, an assessment of the substance aspect of the training module based on competency in-studio operational techniques on problem-based learning (PBL) camera operators for participants with a coefficient of 0.643 "valid" category. While the presentation aspect has a coefficient of 0.643 , the "valid" category, in terms of the language aspect, the coefficient of 0.607 is categorized as "valid".

From these three aspects, it can be concluded that the training module based on competency in-studio operational techniques on problem-based learning (PBL) camera operators for participants has content validity - Aiken's V is declared "valid".

\section{b. Results of Content Validity - Lawshe's VCR}

The results of the Content Validity - Lawshe's VCR, are used to measure agreement among evaluators (validators) about the importance of certain items, in tthe training module based on competency in-studio operational techniques on problem-based learning (PBL) camera operators for participants, the results display can be seen in table 8.

\section{Table 8. Content Validation Results - Lawshe's VCR Competency-Based Training Module for Studio Operational Techniques}

\begin{tabular}{|c|c||c|}
\hline No & Assesors & Category \\
\hline \hline 1 & $\mathrm{Y}$ & Important \\
\hline \hline 2 & $\mathrm{R}$ & Important \\
\hline \hline 3 & $\mathrm{~B}$ & Important \\
\hline \hline 4 & $\mathrm{Y}$ & Important \\
\hline \hline 5 & $\mathrm{R}$ & Important \\
\hline \hline 6 & $\mathrm{~S}$ & Important \\
\hline \hline \multicolumn{2}{|l||}{} & Important category \\
\hline
\end{tabular}

Results of Content Validity - Lawshe's VCR. the training module based on competency in-studio operational techniques on problem-based learning (PBL) camera operators for participants have met the validity of content that is "valid" (good) and is considered important by the experts used as assessors.

c. The training book based on competency in-studio operational techniques on problem-based learning (PBL) For Instructors/resource persons

\section{a. Content Validity - Aiken's V}

The results of the content validity - Aiken's, for training book based on competency in-studio operational techniques on problem-based learning (PBL) for Instructors/resource person can be seen in Table 10 below.

Table 10 Content Validation Results - Aiken's V Studio Operational Technique Competency-Based Training Book About PBL (Problem Based Learning) Camera Operators for instructors/resource persons

\begin{tabular}{|c|c|c|c|c|c|c|}
\hline \multirow[t]{2}{*}{$\begin{array}{c}\text { Assesors } \\
\text { (validator) }\end{array}$} & \multicolumn{2}{|c|}{$\begin{array}{c}\text { Item } 1 \\
\text { (substance) }\end{array}$} & \multicolumn{2}{|c|}{$\begin{array}{c}\text { Item } 2 \\
\text { (presentation } \\
\text { aspecy) }\end{array}$} & \multicolumn{2}{|c|}{$\begin{array}{c}\text { Item } 3 \\
\text { (language } \\
\text { aspect) } \\
\end{array}$} \\
\hline & Score & $\mathrm{S}$ & Score & $\mathbf{s}$ & Score & $\mathrm{S}$ \\
\hline $\mathrm{Y}$ & 4 & 3 & 4 & 3 & 3 & 2 \\
\hline $\mathrm{R}$ & 4 & 3 & 4 & 3 & 4 & 3 \\
\hline B & 4 & 3 & 4 & 3 & 4 & 3 \\
\hline $\mathrm{Y}$ & 4 & 3 & 4 & 3 & 3 & 2 \\
\hline $\mathrm{R}$ & 3 & 2 & 4 & 3 & 4 & 3 \\
\hline
\end{tabular}

\begin{tabular}{|c|c|c|c|c|c|c|}
\hline $\mathrm{S}$ & 4 & 3 & 4 & 3 & 4 & 3 \\
\hline$\sum \mathbf{s}$ & \multicolumn{2}{|c|}{17} & \multicolumn{2}{|c|}{18} & \multicolumn{2}{|c|}{16} \\
\hline $\mathbf{V}$ & \multicolumn{2}{|c|}{0.607 (valid) } & \multicolumn{2}{|c|}{0.643 (valid) } & \multicolumn{2}{|c|}{$\begin{array}{c}0.571 \\
\text { (valid) }\end{array}$} \\
\hline
\end{tabular}

Based on the table 10 above we can draw conclusions. The value of $\mathrm{V}$ for item 1 (substance aspect) is obtained from $\mathrm{V}=17 /(6(5-1))=0.607$, as well as item 2 for the presentation aspect, namely $\mathrm{V}=18(6(5-1))=0.643$ while for items 3 aspects of language, namely $\mathrm{V}=16(6(5-1))=$ 0.571, of the three content validation items-Aiken's $\mathrm{V}$ in table 10 above the training book based on competency instudio operational techniques on problem-based learning (PBL) for Instructors/resource person in category of "valid".

After calculating based on the validity provisions of Aiken's V, based on the criteria for the validity value of Aiken's V, it can be seen in Table 34 that the results of the Aiken's V content validity coefficient in training book based on competency in-studio operational techniques on problembased learning (PBL) for Instructors/resource person is categorized as valid. The final average value of training book based on competency in-studio operational techniques on problem-based learning (PBL) for Instructors/resource person is categorized as valid, an assessment of the substantial aspects with a coefficient of 0.607 and it can be categorized as valid. While the presentation aspect has a coefficient of 0.643 valid category, the language aspect coefficient of 0.571 is categorized as valid. From these three aspects, it can be concluded that training book based on competency in-studio operational techniques on problembased learning (PBL) for Instructors/resource person has content validity - Aiken's V is declared "valid".

\section{b. Content Validity Result - Lawshe's VCR}

Results of Content Validity - Lawshe's VCR, used to measure agreement among evaluators (validators) about the importance of certain items, in the training book for instructors, the results can be seen in table 11 .

Table 11. Content Validation Results - Lawshe's VCR Books Technical Operations Competency Based Training Studio On Camera For Operator PBL Instructor

\begin{tabular}{||c|c|c|}
\hline \hline No & Assesors & Category \\
\hline \hline 1 & Y & Important \\
\hline \hline 2 & R & Important \\
\hline \hline 3 & B & Important \\
\hline \hline 4 & Y & Important \\
\hline \hline 5 & R & Unimportant \\
\hline \hline 6 & S & Important \\
\hline \hline \multicolumn{2}{|l|}{} & Important category \\
\hline
\end{tabular}

From the 6 expert panels, 5 people stated the item was "important", 1 person stated "appropriate, not important", (see table 35). Above from this data, the CVR can then be calculated as follows: CVR $=((5-(6 / 2)) /(6 / 2)$ CVR $=$ 0.667 indicates that the items used have met good content validity and are considered "important" more than half of the experts as evaluators can be seen in table 11 above. 
Table 12. Summary of Content Validity Test - Aiken's V Competency-Based Training Model Development Operational Techniques Studio About PBL

\begin{tabular}{|c|c|c|c|}
\hline \multirow{2}{*}{ No } & \multirow{2}{*}{ Research Product } & \multicolumn{2}{|c|}{ Validation Product } \\
\hline & & Average & Category \\
\hline 1 & $\begin{array}{l}\text { Training model book based on } \\
\text { studio operational technique } \\
\text { competency about PBL learning } \\
\text { for camera operators. }\end{array}$ & 0,571 & Valid \\
\hline 2 & $\begin{array}{l}\text { The training program, syllabus, } \\
\text { and training lesson plans. }\end{array}$ & 0,607 & Valid \\
\hline 3 & $\begin{array}{l}\text { The training book of Studio } \\
\text { operational technique } \\
\text { competency-based on PBL } \\
\text { learning for participants }\end{array}$ & 0,631 & Valid \\
\hline 4 & $\begin{array}{l}\text { The training book of Studio } \\
\text { operational technique } \\
\text { competency-based on PBL } \\
\text { learning for instructors/resource } \\
\text { persons/facilitators }\end{array}$ & 0,607 & Valid \\
\hline & Result of validation & 0,604 & Valid \\
\hline
\end{tabular}

\section{IV.DISSCUSSION}

The discussion in this section includes the development of a competency-based training model on problem-based learning (PBL) and the validity, practicality, and effectiveness of research products.

\section{Development of Competency-Based Training for Studio Operational Techniques About PBL Learning for Camera Operators}

\section{a. Implementation of PBL for Camera Operators}

The results of preliminary observations about lesson plans showed that there were instructors who did not make it for several reasons. The lesson plan is very important to be made by the instructor as a sign or reference for the instructor in carrying out learning. This was confirmed by the instructors. In fact, they did not know that the lesson plan was very important. This phenomenon shows that the instructor does not have preparation in teaching participants, so that the learning steps, methods, and learning media used are not in accordance with the material being studied. This is a symptom that the instructor does not have innovation in teaching participants which results in them being bored or not concentrating on learning.

\section{a. Competency-Based Training Development Regarding Problem Based Learning (PBL) for Studio Operations Techniques}

The training held is aimed to make camera operator instructor participants understand the theory and be able to practice PBL learning for camera operators in the institutions where the participants are on duty. The results of interviews with participants who have attended training show that most of them do not implement training materials in the respective assignments, it can be stated that they are not placed in the training positions they have participated in so that the knowledge gained cannot be implemented, the problem is This is due to the lack of other operational technical personnel as result participants are multidimensional in their work. Chapter II. Competencybased training on problem-based learning (PBL) contains procedures and structures for competency-based training programs and their descriptions. The competency-based training implementation procedure contains the stages of competency-based training activities starting from registration, opening training, pre-test, face-to-face training, post-test, implementation, evaluation, and closing. The training implementation procedure aims to ensure that participants know and follow every step of the training. Chapter III. the implementation of competency-based training is an explanation given to participants about the place and time of the training. Chapter IV also describes the infrastructure used when participants attend the training. The training methods used are discussion, brainstorming, assignment, and presentation. This method was chosen because it is in accordance with the principles of adult learning, that they learn to share experiences with their friends. Another competency that a resource person/facilitator/instructor must have according to Kirkpatrick and Kirkpatrick [6]. "The selection of instructors is critical to the success of a program. Their qualifications should include a knowledge of the subject being taught, a desire to teach, the ability to communicate, skill at getting people to participate. They should also be "learner oriented" have a strong desire to meet learner needs". The assessment criteria carried out in competencybased training are explained to participants so that they meet the aspects being assessed. The aspects assessed consist of pre-test, post-test, and skills in applying problem-based learning (PBL) in each class. The authentic assessment according to Moore [8] follows.

"Authentic assessment is any type of assessment that requires students to demonstrate skills and competencies that required to integrate knowledge and to complete tasks that have real-life applications".

Pendapat diatas dipahami bahwa penilaian autentik menuntut peserta menunjukkan kompetensi yang diperlukan untuk mengintegrasikan pengetahuan dan untuk menyelesaikan tugas-tugas yang merupakan aplikasi terhadap kehidupan nyata.

Chapter V. closing contains the rules of conduct for participants and resource persons or facilitators.

1)

Training Program, Syllabus, and Lesson Plan Training

The training lesson plan is structured to follow five PBL learning steps. These steps were chosen so that participants could learn theory and experience first-hand PBL learning. This is supported by the opinion of Knowles, Holton III, and Swanson (2005: 39). "adults are motivated to learn as they experience needs and interests that learning will satisfy; therefore, these are the appropriate starting points for organizing adut learning activities". Adults are motivated to learn and interest in learning increases when they experience what they learn, thus it is an excellent starting point for managing adult learning activities. The training lesson plan is made to be guided by the resource person when teaching training participants.

\section{PBL Learning Design Module}

The module is made for participants so that they can learn about PBL learning independently. According to Donnely and Fitzmawarice. (2005) "we are taking a module to be a self contained, formally structured learning experience with a coherent and explicit set of learning outcomes and assessment". Modules are utilized for independent study, learning experiences are well structured and learning outcomes and assessments can be seen clearly. 
The learning experience is structured because the module explains the instructions and criteria that the reader must achieve in order to learn each material. Learning outcomes and assessments are clearly visible because each module is equipped with a formative assessment in the form of multiple-choice tests. The formulas and completeness criteria are also presented so that readers can quickly measure the completeness criteria.

The material discussed in the PBL learning design module is in accordance with the material studied in competency-based training. The contents of the module are basic concepts, steps, and evaluation of problem-based learning. This module helps participants better understand the eight steps of PBL learning. This module consists of a chart image, an introduction, learning activities 1 to 3 , answer keys for formative tests, and a bibliography. Participants need to know this so that they can learn independently according to their respective abilities. The introduction contains the general concepts of PBL learning. This concept is explained with the aim of the participants being able to generally understand PBL learning. Furthermore, it explains the objectives that must be achieved by the participants after studying this module thoroughly. It is intended that participants master the material in the module and finally the contents of this introduction are learning instructions.

Study instructions are a guide for participants to understand the module content well, this is important to know so that they can master PBL learning materials thoroughly.

The contents of the next module are learning activities consisting of material descriptions, exercises, summaries, and formative tests. The material description contains an explanation of the basic concepts, steps, and evaluation of PBL learning. Then the exercise was completed by the participants to deepen their understanding of the material discussed. These exercises are three or one essay-type questions. This exercise is also equipped with instructions for answering questions so that they do not encounter problems when answering them. The summary contains a brief explanation of the core topics of the material description. This summary is aimed to ensure that participants know the core topics that must be understood. Furthermore, in each learning activity, there is a formative test. The formative test aims to measure the participants' mastery of the material being studied. This formative test consists of 10 questions in the form of multiple-choice with four alternative answers. The questions in the formative test are adjusted to the material description. At the end of the formative test, it is explained how to calculate the percentage of mastery of the material by participants. They can self-evaluate their mastery of the learning material that has been read. The formative test answer key helps participants find out the correct answer so that they can calculate the percentage of mastery.

\section{1) Competency-Based Training Book About}

\section{Problem Based Learning (PBL)}

A competency-based training book on PBL learning contains steps for implementing competency-based training. The competency-based training steps in this book are very operational so that it can be followed by institutions or individuals who want to develop competency-based training. It also can be used in other training materials. This book consists of three important parts, namely, introduction, competency-based training, and closing. The introduction containing the background needs to be explained so that competency-based training has a strong enough basis to be implemented. The competency-based training section discusses the stages of activities carried out. This competency-based training is divided into several stages of activities, the first is training needs analysis, the second is training design, and the third is training implementation. In the training needs analysis activity stage, the theory and how to do it are explained. This is done to see the comparison between theory and practice carried out on the training needs analysis. Designing competency-based training, including activities to make program structures, descriptions, training lesson plans, schedules, and evaluations. The material given to participants in competency-based training is PBL learning. Implementation of face-to-face training using PBL learning steps Direct experience of the material being studied makes it easier for participants to understand and practice PBL learning in the place of each participant's assignment. Based on this opinion, the learning design must plan a conducive environment that supports the achievement of the desired goals or behavior. Evaluation of cognitive training materials by means of pre-test and post-test. The pre-test and post-test questions used a multiple-choice and matchmaking written test. This form of the test was chosen so that it can be seen quickly how the participants' mastery of the training material increased. This is consistent with Moore's [8] opinion that multiple-choice and matchmaking tests have the following advantages and disadvantages. "Multiple choices advantages: (1) large sampling of content, (2) Scoring simple and fast, (3) Measures wide range of cognitive levels, and (4) Reduces guessing. Disadvantages: (1) Question Construction time-consuming and (2) Often used to test trivial content. Matching advantages: (1) large sampling of content, (2) can test association, and (3) easy to construct and score. Disadvantages: (1) test for recognition and (2) guessing".

Implementation of competency-based training with PBL learning materials, starting with participants registering, officially opening training, carrying out pre-tests, face-toface training, post-testing, implementing, evaluating, and officially closing. The implementation of the training uses a systematic procedure to minimize the obstacles encountered in carrying it out. Registration aims to make sure that the number of participants and their identities is clearly known so that no participants are absent and orderly in following each training material session.

The success of the training highly depends on the availability of teaching materials comprising training material modules, guides, training lesson plans.

\section{V.VALIDITY, PRACTICALITY, AND EFFECTIVENESS OF RESEARCH PRODUCTS.}

Research products have met the criteria of validity, practicality, and effectiveness, this is in accordance with Akker's opinion [1] "during development processes, the emphasis in criteria for quality usually shifts from validity to practicality, to effectiveness". 
The discussion of research products is described below.

\section{a. Research product validity}

All materials for research were validated by three experts. The validated research materials were model books, participant books (modules), instructor books on PBL learning, pre-test post-test questions, and implementation observation guides. The results of the validation of the research materials were stated in the valid category after several revisions were made.

This is in accordance with the opinion of Plomp [11 [; Nieveen [9]; and Nieveen [10] that "the components of the material should be based on state-of-the-art knowledge (content validity) and all components should be consistently linked to each other (construct validity)".

Competency-based training is developed from several training theories including CEM (1982), Goad (1982), Dubois (1996). Based on these theories, it is known that the steps of a series of training procedures end with giving tests to participants, and no follow-up is given to implement them in each participant's workplace. On this basis, a series of training activities were continued by providing group guidance to participants to implement training materials in their respective workplaces. To carry out competency-based training on PBL learning to be successful, validated supporting materials are needed.

\section{Competency Based Training Instructor Book About PBL Learning}

This competency-based training instructor book has very valid criteria after several consultations with the validator and corrected. This guide is intended for instructors, in carrying out competency-based training on PBL learning. In the background, there are several things that are explained including the change in the instructor's paradigm in learning and the reasons for holding competency-based training. It is important for the participants to be informed so that they are willing to open up to receive innovations in implementing training materials. It is intended that participants can prepare themselves and contribute to all competency-based training activities. The training lesson plan is a learning step that must be followed by the resource person in teaching training participants. The lesson plan is made for each main training material. The training lesson plan has very valid criteria. This proves that the training lesson plan is in accordance with the PBL learning theory. The material provided in faceto-face training and learning activities uses PBL learning steps proposed by Aris Shoimin [13]. The learning materials and activities go hand in hand, so that participants have direct experience of PBL learning theory and practice.

\section{PBL Learning Design Modul}

The validator states that the PBL learning design module has very valid criteria after being revised several times. The PBL learning design module contains a description of the training material. Many improvements have been made in this module such as exchanging theories on behavior structure because the theory used is appropriate and needs to be added to constructivist theory so that it will become stronger in theory because the constructivist theory is in accordance with the training theory at the Pusdiklat. It has been added after discussion with the promoter.

\section{Competency Based Training Instructor Book About PBL Learning}

The training book was created as a guide for instructors, resource persons, and managing facilitators in carrying out competency-based training on PBL learning. The results of the three validators' assessment showed that the competency-based training book on PBL learning was in accordance with the existing theory so it was feasible to use.

\section{1) Pre-test and Post-test}

The pre-test, post-test questions are in the very valid category. This shows that the pre-test and post-test items are in accordance with the competency-based training material on PBL learning. Initially, the pre-test and post-test questions were in the form of an essay consisting of five questions, and each of them was given an assessment weight. This caused the validator to suggest that this essay question be replaced with multiple-choice and matchmaking questions. There are 20 multiple-choice questions and 10 matching questions. This question was chosen because it avoids being subjective and can quickly see the comparison of the correct answers between the pre-test and post-test.

\section{Implementation Observation Guide}

The results of the validator's assessment state that this observation guide is very valid. This proves that this observation guide is in accordance with the five steps of PBL learning that were trained to the participants. This observation guide is closed, meaning that the results of the observations have alternative answers. The advice given by the validator for this guide is to improve the sentence and separate the observation points with different answers.

\section{VI.CONCLUSION}

Based on the results of the research, that the development of competency-based training on PBL (problem-based learning) is feasible to use after being considered valid, according to the following criteria. The development of competency-based training is considered valid after the experts state that it is in accordance with the theory and is related to one another. Training materials with valid values are competency-based training guides on problem-based learning for participants, competency-based training books on PBL (problem-based learning) learning for instructors, training programs and training lesson plans, and competency-based training design modules.

The results of this development prove that face-to-face training followed by group guidance to participants can help them improve their knowledge and skills about the material being studied. Training materials on PBL (problem-based learning) were selected based on an analysis of training needs. This supports the implementation of [12] SKKNI no. 81 of 2014 .. This development could have implications for training institutions such as the TVRI Pusdiklat Institute to use this competency-based research procedure.

Based on the research results, it can be suggested to other researchers can conduct competency-based training development research on other materials or carry out further research by implementing individual training or blended training.

\section{ACKNOWLEGMENT}

Thank you very much to the promoter, Prof. Dr. Nizwardi Jalinus, M.Ed., and Prof. Dr. Jamaris Jamna, M.Pd. thanks to his guidance and care, this article was finally completed.

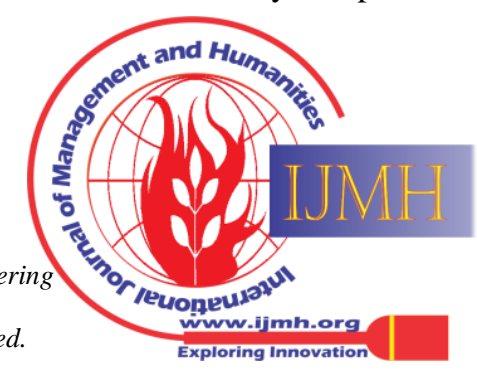


Thank you also to all the academicians of Padang State University who have helped a lot in completing this article. Once again, thank you so much.

\section{REFERENCES}

1. Akker, Jan Van Den. (1999). Principles and Methods of Development Research. In Design Approaches and Tools in Education and Training. Edited by Akker, Jan Van Den etc. Netherlands: Kluwer Academic Publishers.

2. BSNP. (2007. Standar Isi. (Online). http://bsnpindonesia.org.id/page_id-103/. (diakses 24 Maret 2019). Pukul 21.25.

3. BSNP. 2007. Peraturan Menteri Pendidikan Nasional Republik Indonesia Nomor 41 Tahun 2007 Tentang Standar Proses untuk Satuan Pendidikan Dasar dan Menengah. Jakarta: BSNP.

4. Dubois, D. (1996). The executive guide to competency-based performance improvement. HRD press harvest.

5. Gijbels, D, Dochy, F dan Van de Bossche,F. (2005). Effects of The Problem Based Learning. A Meta-analysis from the Angle Measurement. Journal Review of Educational Research. Vol. 75-49.

6. Kirkpatrick, Donald L and Kirkpatrick, James D. (2006). Evaluating Training Programs: the Four Levels. San Fransisco: Berrett - Koehler Publishers, Inc.

7. Levin, B. (Ed). (2001). Energizing Teacher Education And Profesional Devlopment With Problem-Based Learning. Alexandria, VA: Association for Supervision and Curriculum Development.

8. Moore, Kenneth D. (2005). Effective Instructional Strategies: From Theory to Practice. California: Sage Publications

9. Nieveen, Nienke. (1999). Prototyping to Reach Product Quality. In Approaches and Tools in Education and Training. Edited by Akker, Jan Van Den etc. Netherlands: Kluwer Academic Publishers.

10. Nieveen, Nienke. (2010). Formative Evaluation in Eduational Design Research. Dalam Tjeer Plom and Nienke Nieeveen (Ed). An Intro-duction to Educational Design Research. (p:9-35) Netherlands in www.slo.nl/organisatie/inter-national/ publications.

11. Plomp, Tjeerd. (2010). Educational Design Research: an Introduction. In An Introduction to Educational Design Research. Proceedings of the Seminar Conducted at the East China Normal University, Shanghai (PR China), November 23-26, 2007. Edited by Plomp, Tjeerd and Nieveen, Nienkee. Netherlands: SLO Netherlands Institute for Curriculum Development.

12. SKKNI Kementerian Tenaga Kerja dan Transmigrasi No 81 Tahun 2014, tentang Operator Kamera/ Juru Kamera, dengan kode unit R.9000030.005.01, Judul unit: menyusun Komposisi Dalam Pengoperasian Kamera.

13. Shoimin, Aris. 2014. 68 Model Pembelajaran Inovatif Dalam Kurikulum 2013. Yogyakarta: Ar-Ruzz Media.

14. Sears, Susan Jones and Hersh,Susan B. 2001. Contextual Teaching and Learning: An Overview of the Project. In Contextual Teaching and Learning: Preparing Teacher to Enhance Student Success in the Workplace and Beyond. Edited by Howey, Kenneth R etc. Columbus: ERIC Clearinghouse on Adult, Career, and Vocational Education Center on Education and Training for Employment.

\section{AUTHOR PROFILE}

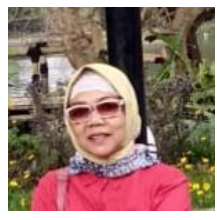

Ezriani, Lahir di Palembang, 24 Maret 1966 Pendidikan S1 Universitas Negeri Padang, S2 Universitas Negeri Padang, dan S3 Universitas Negeri Padang , Bekerja di TVRI Pusat Jakarta

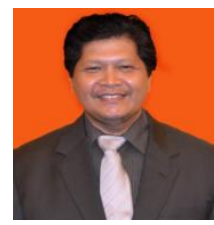

Nizwardi Jalinus Professor

Lahir pada 22 Agustus 1952 di Palembang. Beberapa artkel yang telah ditulis seperti

1. Media dan Sumber Pembelajaran

$2 . \quad$ The seven steps of project based learning model to enhance productive competences of vocational students

3. Implementation of the PjBL model to enhance problem solving skill and skill competency of community college students.

4. The create skills of vocational student design a product; comparison project based learning versus cooperative learning-project based learning.

5. Influence of learning strategy of cognitive conflict on student misconception in computational physics course.
6. Pengembangan pendidikan technology dan kejuruan dan hubungan dunia kerja.

7. Evaluasi kinerja guru sekolah menengah kejuruan Sumatera Barat pascasertificasi.

8. Kurikulum pendidikan vokasi pada era revolusi industry 4.0

9. Peran media social dalam upaya promosi kesehatan; tinjauan literature.

10. The instructional media development of welding practice course based on PjBL model; enhancing student engagement and student competences.

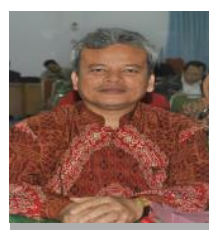

Jamaris Jamna, Profesor

Lahir di nanggalo Pesisir Selatan pada 10 Oktober 1962 Beberapa artikel yang pernah ditulis yakni

1. Badan Standar Nasional Pendidikan

2. Pendidikan Matrilineal

3. Penerapan Pembelajaran Orang Dewasa oleh Instruktur Pelatihan Keterampilan Menjahit di SPNF SKB Lima Puluh Kota

4. Efektivitas Team Assisted Individualization untuk Mengurangi Prokrastinasi Akademik

5. Pentingnya Pemahaman Orang Tua tentang Karakteristik Pembelajaran AUD dalam Penerapan Model Environmental Print Berbasis Keluarga untuk Meningkatkan Kemampuan Membaca Awal Anak

6. Paradigm Pendidikan Nasional Abad XXI

7. Efektivitas Pelaksanaan Bimbingan Kelompok dengan Pendekatan Konseling Realitas dalam Mengembangkan Penyesuaian Diri Siswa di Lingkungan Sekolah pada Siswa Kelas X SMA

8. Penerapan Prinsip Andragogik oleh Tutor pada Pelatihan make Up Wardah Cosmetic di Kota Padang.

9. Stimulation of Groslmproving Children's Early Reading Skills Using Home Environmental Print Models Motor Development in Early Childhood

10. Factors Causing Low Participation of Natural Parents Stimulaties the Ability of Early Reading of Children Natural Family

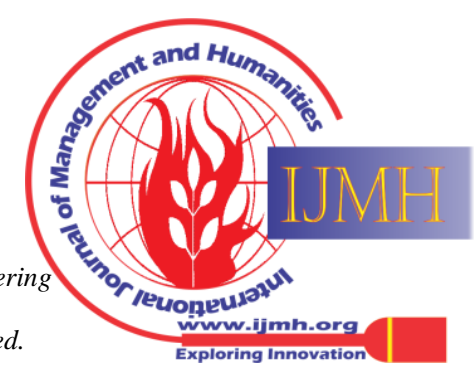

